\title{
Social Value Creation and Institution-Entrepreneurial Dynamics in a Three Sector Economy
}

\author{
Gift Dafuleya \\ University of Venda, Thohoyandou, South Africa \\ gift.dafuleya@univen.ac.za
}

\begin{abstract}
This paper attempts to answer the question: who creates social value in an economy, for whom and how? By examining the focal institutions that operate in a three sector economy, the paper, at the risk of oversimplifying and over narrowing the scope, develops an institution-entrepreneurial matrix that categorise institutions and provides clarity on the field of play. Coupling this with an institutions-actions model, the paper creates two scenarios of institution-entrepreneurial dynamics within the context of social value creation. The analysis demonstrate that mission drifts that adjust the realm of organizations are inevitable, but need to be carefully managed to avoid mix-up on who does what, for whom and how. At the heart of the discussion is the role of social entrepreneurs whose creation of social value to the segment of humanity in an unjust equilibrium is slightly distinct from the rest. Their unique realm lies in the realisation of nuanced pare to improvements.
\end{abstract}

Keywords: Social value creation; institution-entrepreneurial dynamics; three sector economy; social entrepreneurs; pare to improvements

\section{Introduction}

Most economies in the developing world are faced with significant proportions of people living in poverty. Their poverty is multifaceted, ranging from social to financial exclusion and from lacking access to clean water to lacking education that leads to innovation which they need to transform themselves. In the developed world, economies are also faced with societal problems such as unemployment although the magnitude is incomparable to that of the developing countries. In all these economies, there is an "unjust equilibrium that causes the exclusion, marginalisation, or suffering of a segment of humanity that lacks the financial means or political clout to achieve any transformative benefit on its own" (Martin and Osberg, 2007: 35). Who, among several economic agents, is interested in finding solutions to these problems to this segment of humanity? Answering this question possibly borders on the issue of social value creation defined by Phills et al. (2008) as the creation of benefits for the society that go beyond market transactions. Asked differently, the question becomes, who creates social value in an economy, for whom and how?

Theory and empirical evidence (for example, see Emerson and Twersky, 1996; Dees and Anderson, 2003; Austin et al., 2006; Dees and Anderson, 2006; Acs et al., 2011) suggests that answering this question is far from a common ground understanding. If anything, social entrepreneurship has become the catchphrase that is used to define institutions or persons creating social value (Zadek and Thake, 1997) to a targeted group that lacks financial means to graduate out of suffering (Martin and Osberg, 2007) through value expressed in exchange and market transaction (Bruyat and Julien, 2001). On the contrary, Acs et al. (2011) argue that commercial entrepreneurship is equally capable of creating social value to an extant of pointing out that separating the two is not useful. Barro (2007) shows how market value of goods sold to customers create social value to the same customers. Auerswald (2009) agrees that there is no dispute on the fact that commercial entrepreneurship creates social value, however, he opines that what is in dispute is the type and quantity of social value. But then, Austin et al. (2006) have differentiated these two types of entrepreneurship based on social value proposition. But then again, some researchers (see Thompson, 2002) understand social entrepreneurship as non-profit organisations which adopt innovative, for-profit activities to earn income, without necessarily dwelling much on social value creation. Furthermore, when for-profit organisations adopt and pursue social good, the result seemingly creates corporate social 
responsibility and not social entrepreneurship. ${ }^{1}$ The result is a mixed-up cog with dire consequences for theory, practice and public policy.

Accordingly, this paper aims to address this question by developing an institution-entrepreneurial matrix that categorises different institutions and provides clarity on the field of play. It does so at the risk of oversimplifying and over-narrowing the scope of institutions operating within the three sectors of the economy. Then, using insights from institutions-actions model, it demonstrates that institutionalentrepreneurial dynamics that adjust the realm of institutions are unavoidable, but need to be carefully managed to avoid mix-up on who does what, how and for whom. At the heart of the discussion is the role of social entrepreneurs who are understood to be well positioned to offer nuanced pare to improvements - benefiting others without hurting others - and be the new economic fuel for developing economies. The realm of social entrepreneurship is especially important for developing economies where a significant part of the world population is financially and socially excluded and does not have the capacity to transform themselves out of their problems. In some of these economies, governments fail to perform their roles. The private sector is a minor domain because the majority of the population may not engage in market exchange for lack of financial means. NPOs that drive common interests are weak or not present at all. NGOs may not be allowed to operate, or if they are, they will be overwhelmed with demand to achieve transformative social welfare. There is, therefore, a role for entrepreneurs that can identify problems associated with societies living in these economies, develop sustainable innovative entrepreneurial activities to address the problems and transform societies out of misery. The paper posits that while most institutions are able to accomplish this, social entrepreneurship could be at an advantage in accomplishing this transformation. The next section provides the definition and conceptual framework within the three sector economy background derived from extant literature. Then the institutions-actions model is presented before the section that uses this model, together with the institution-entrepreneurial matrix that forms the conceptual framework, to create scenarios of institution-entrepreneurial dynamics within the social value creation context. This is followed by a discussion on the implications for theory, practice and public policy and then the paper concludes by a summary and suggestion for future research.

\section{Social Value Creation in the Three Sector Economy}

There are three fundamental questions that each economy is faced with - 'What should be produced'? 'How should it be produced'? 'For whom should it be produced'? An economy can be conceptualised as comprising of three sectors (Billis, 1993; Pearce, 2003). Firstly, there is the private sector, which consists of individuals mostly driven by self-interest, that determines what to produce and for whom through price. Secondly, there is the public sector comprising of the state institutions and publicly owned and funded institutions that are especially aimed at producing goods and services that may not be provided under the private sector. Thirdly, there is a social sector established by institutions, in most cases on a voluntary basis, to pursue social, community and charity goals (Ridly-Duff and Bull, 2011) which otherwise would never be pursued by the public and private sectors. Table 1 categorises these sectors and shows the type of institution (defined as shared norms that identify categories of actors and their activities (Burns and Flam, 1987)) operating in each of the sectors. In this categorisation, the three fundamental questions are posed within the social value creation context - who creates social value in the three sector economy, for whom and how?

There are many forms of value that exist. These include cultural value (Bourdieu, 1993), creative value (Godelier, 1999), economic value (Mair and Marti, 2006; Peredo and Mclean, 2006) and social value (Auerswald, 2009; Ormiston and Seymour, 2011) amongst others. The paper concentrates largely on social value and slightly on economic value. Phills et al. (2008) defines social value as the creation of benefits for society in ways that go beyond market transactions. The emphasis on social value creation is on benefiting the parts of the society with urgent livelihood needs that are not being met by any other means (Young, 2006). Social value creation may include poverty reduction, reducing social and financial exclusion, providing access to education and health care among other socially motivated themes

\footnotetext{
${ }^{1}$ The Journal of Social Entrepreneurship, in its Aim and Scope, posits that social entrepreneurship includes both for and not-for profit organisations but excludes “....all organisations whose primary purpose is profit maximisation, irrespective of whether they also aim to do social good" and that "this falls under... (a) separate heading of Corporate Social Responsibility..."

[http://www.tandfonline.com/action/aboutThisJournal?show=aimsScope\&journalCode=rjse20, accessed on 02 June 2012).

The issue of explicitly stating the purpose of an organisation, as a defining feature of social entrepreneurship, is strongly challenged by Acs et al. (2011). According to them "...an entrepreneur can state social goals (as a primary purpose) without actually creating social value".
} 
(Nicholls, 2006). The targeted group usually lack financial power to achieve any transformation through exchange and market transactions (Martin and Osberg, 2007). The desire to benefit such a group makes social value creation salient (Perrini and Vurro, 2006). Financial profit is basically used as a proxy for economic value (Nicholls, 2006) and result if value realised on a sale is greater than the costs involved (Bowman and Ambrosini, 2000). Economic value may (may not) create social value in instances where there are producer and consumer surpluses (Auerswald, 2009) with (without) positive externalities of their transactions to the general society. For example, a market transaction that involves an individual who produces apples and an individual who buys and consumes apples usually does not have external benefits to the society. However, it may still be argued that the same market transaction has positive externalities through the contribution of the producer to economic growth (see Ahmad and Hoffmann, 2008). The positive externalities may impact an individual, group or the society at large. Therefore, the social value creation that derives from economic value may be thought of as multi-layered.

Table 1: Three Sectors of the Economy

\begin{tabular}{|c|c|c|c|}
\hline & Private Sector & Public Sector & Social Sector \\
\hline \multirow[t]{7}{*}{ Institutions } & Sole proprietorships & Government & - Cooperatives \\
\hline & Micro, Small and & Government-owned or & Unions (e.g. Labour \\
\hline & Partnerships & & - Community-Based \\
\hline & Large & & Organisations \\
\hline & Corporations & & - Not-for-Profit \\
\hline & Multinational & & Organisations \\
\hline & Corporations & & $\begin{array}{l}\text { - Voluntary associations } \\
\text { - Social enterprises }\end{array}$ \\
\hline \multirow[t]{2}{*}{ Dominant Characteristic } & & & \\
\hline & $\begin{array}{l}\text { Private economic return } \\
\text { and efficiency }\end{array}$ & $\begin{array}{l}\text { Redistribution and } \\
\text { provision of public } \\
\text { goods and services }\end{array}$ & $\begin{array}{l}\text { Self-help and } \\
\text { purpose }\end{array}$ \\
\hline
\end{tabular}

Another layer of the social value created through economic value can be seen through market transactions in the telecommunications industry. Innovations in this industry have impacted the way people relate to one another. While there is no doubt that there is economic value created, there is social value that is also created through social bonding that results in higher levels of social capital (Putman, 2001; Woolcock, 2001; Acs et al., 2011). The client, in this context, values the social relations more than the money paid, and can arguably be seen as pursuing social value. However, if this is scrutinised in the lens of positive externality, the social capital will be understood as a private resource for the communicating clients that have not created a positive externality to the general public. Whilst acknowledging that social value creation is multi-layered, a narrow conceptualisation of social value creation is used in this paper. Social value is defined as the benefits directly targeted to the part of the society that lacks social, financial and political means to achieve exit trajectories from their social problems. This definition is narrow in that it excludes any positive externalities from market transaction that have a chance of impacting anyone, including groups with social, financial and political means. Furthermore, the definition excludes any social value created at an individual level.

The Private Sector: Institutions operating in the private sector can be understood as pursuing an entrepreneurial profit (Schumpeter, 2011). The umbrella term, commercial entrepreneurship ${ }^{2}$, is used to represent all institutions operating in this sector. There are many approaches that have been used to describe commercial entrepreneurship. Schumpeter (1934) described commercial entrepreneurship as the process of capitalism that moves the economy forward through innovation. A significant number of approaches to commercial entrepreneurship base on ideas put forward by Schumpeter. For instance, Quinn and Cameron (1983), Burgelman (1983, 1984), and Timmons and Bygrave (1986) accentuate innovation within organisational life cycles, established corporations, and start-ups and venture capital respectively. Other approaches have stressed on profit or reward within the context of opportunity recognition (Casson, 1982; Stevenson, 1983, 1985; Stevenson and Jarillo, 1991; Singh, 2001), exploiters of change (Druker, 1995) who are alert (Kirzner, 1973) in using such changes to create business

${ }^{2}$ The umbrella term used could have been business entrepreneurship, market entrepreneurship, or economic entrepreneurship. All these terms are summarised as commercial entrepreneurship in order to avoid an overabundance of working terms. 
opportunities and willingness to bear the inherent risk (Martin and Osberg, 2007), while others emphasize on the psychological and sociological characteristics (McClelland, 1961; Collins and Moore, 1964; Cunningham and Lischeron, 1991). ${ }^{3}$

Baumol (1990) added to Schumpeter's work by underscoring that entrepreneurship can be productive, unproductive and destructive. Productive entrepreneurship creates social value along with profits (Weitzel et al., 2010). Destructive entrepreneurship decreases social value (Desai and Acs, 2009). On the other end, Light (2006) and Mair and Marti (2006) posit that conceptualising entrepreneurship should be modified to include both the economic and social value creation. In this context, the sale of a good or service in the private sector simultaneously creates both economic value to those involved in the exchange and social value indirectly through their effect on economic growth, contribution to employment and poverty reduction (Ahmad and Hoffmann, 2008; Barro, 2007). Given this review, the working definition of commercial entrepreneurship used in this paper is - a for-profit institution, operating for private gain that creates economic value directly to those who can pay for the goods and services that it offers, and indirectly (or not at all) to the society at large.

The Public Sector: The reference point for the existence of the public sector in the economy is that, in the presence of imperfect information or incomplete markets, the market will not produce efficient allocations. Accordingly, the government may need to intervene to make everyone better off (Greenwald and Stiglitz, 1998). Coase (1960) opines otherwise. He claims that if markets are inefficient, people will negotiate their way to efficiency. In essence, he draws our attention back to the invisible hand (Smith, 1776). But Coase's conjecture has been criticised on the grounds of being too ambitious (Farell, 1987), offering little guidance on crucial matters (Stiglitz, 1994; Dixit and Olson, 1997) and tempting policy makers to relax in the face of market failures (Calabresi, 1968). As such, the public sector has been generally understood as existing to further the common interest of the public (Olson, 1971). It uses authority of the state to compel individuals or institutions to contribute to social value creation. For example, every employed citizen may be obliged to pay tax to extend social protection to the poor, and polluters are taxed to achieve a socially optimal quantity of pollution.

At this juncture, it is important to point out that there is a blurred line between what is public and what is private (Musolf and Seldman, 1980). This blurring is especially pronounced for a category of institutions known as government-sponsored enterprises (Moe and Stanton, 1989) and public enterprises (Peltzman, 1971) ${ }^{4}$ As expressed by Moe and Stanton and Peltzman, government-sponsored enterprises in the United States are chartered by act of Congress to accomplish public purposes, yet they are privately owned; also, public enterprises are owned and operated by groups acting for society through the state. Although these types of enterprises are different from commercial enterprises, it is wise to acknowledge their similar characteristics that overlap the boundaries of public and private sectors, and without a doubt this is innovative and inevitable (Bozemann, 1987). However, for ease of conceptualisation, this paper bundles government-sponsored and public enterprises within the term 'government', hence limiting them to the public sector. In fact Moe (1987) favours such categorisation to be maintained for the sake of order and responsible system of government. Accordingly, the working definition of a government is a not-for-profit institution owned by all citizens of a given economy, but managed by a group of people elected to represent the citizens, that attempts to create social value through counterbalancing market failure by providing public goods and redistribution of resources.

The Social Sector: The social sector is an alternative to public and private sectors that, debatably, disempowers citizens (Morrison, 1991). Institutions that mainly make up this sector are established to primarily pursue social, community and charity goals (Ridly-Duff and Bull, 2011) which otherwise would never be pursued by the public and private sectors, or where both the government and the markets have failed. Most of these institutions share a common social goal of reducing social exclusion in a variety of ways. These ways include providing services cheaply or at no cost to disadvantaged groups and adopting strategies that channel income to the poor (Ridly-Duff and Bull, 2011). On the other hand, some of the institutions are made of individuals who pursue common interest limited to their members. In essence, this is a not-for profit institution that pursues common interests for members only. Institutions of this nature are similar to institutions that further interests of shareholders (Olson, 1971) with the only difference being that they are not profit making. This calls for further probing of institutions

\footnotetext{
${ }^{3}$ Cunningham and Lischeron provide six schools of thought about entrepreneurship in the literature.

${ }^{4}$ These institutions are also known as government enterprises and government owned enterprises.
} 
conceptualised as operating in this sector. The paper separately scrutinise three institutions, that are arguably assumed to be major in the social sector, below.

Non-government organisations (NGOS): Although definitions of NGOs tend to vary, they are best known as service providers (Leonard, 2002; Jagannathan, 2003; Bennett et al., 2003; Reinikka and Svensson, 2003), organising policy advocacy, public campaigns and lobbying governments (Besley and Ghatak, 1999; Scott and Hopkins, 1999; Cannon, 2000) in the interest of the public. Fascinating are NGOs that are either community based or, at least, originate from domestic processes to face social challenges that have long been recognised in the social sector in experimenting with funding of their activities (Barr et al., 2005). For instance, Bangladeshi community-based NGOs have attracted funding from different donors, and have emerged strongly in the provision of microfinance to the financially excluded members of the society (Morduch, 1999).

Not-for-profit Organisation (NPOS): It is the interest of serving the public or community at large that is used to differentiate NGOs from NPOs. ${ }^{5}$ While both institutions can be characterised by voluntarism, selfgovernance, independence and non-distribution of profits to members (Glaeser, 2003; Salamon and Anheier, 1996), NPOs do not have a charitable or philanthropic purpose (Barr et al., 2005). Two examples may be proffered to validate this assertion. One, a building society may be established as an NPO that seeks to address housing challenges of its members only (and not of the community at large). Two, labour unions are expected to bargain for better working conditions and protect employment for their members only. In the event that a worker is not a member, and is illegally dismissed from employment, the union will not fight for that worker. Olson (1971) argues that the common interests of NPOs may not even be pursued unless there is coercion or other devices to compel members therein to act in their common interest. So if this is the case, it may not be easy to pursue a goal for social (outside the group) value creation?

Community-based and social enterprises: Communities used to be treated as exogenous to entrepreneurship (Gartner, 1985; Learned, 1992; Bhave, 1994). However, there is now substantial literature that has treated entrepreneurship as an embedded part of the local community (Taylor, 1999; Kilkenny et al., 1999; Johannisson et al., 2002). A combination of a community-based organisation (CBO) and enterprising in pursuit of social good produces a community-based enterprise (Peredo and Chrisman, 2006). This assertion is closely related to literature dealing with social enterprises (Mort et al., 2003; Haugh and Tracey, 2004), defined by the authors as NPOs engaged in commercial entrepreneurial activities and driven by a social or public purpose. Therefore, the paper uses the terms community-based enterprises and social enterprises as institutional expressions of entrepreneurship embedded with a social goal stated explicitly in its mission (Mendell, 2010). It has been emphasized that institutions termed as social enterprises in the social sector need to pursue a social or public purpose to reach the parts of the society that the public and private sectors do not reach (Dees et al., 2004), in addition to developing for-profit ventures to generate income for their mission. In this context, applying business expertise or pursuing commercial entrepreneurial activities by NPOs or CBOs is a necessary, but not sufficient, condition for these institutions to be labelled as social enterprises. Otherwise there is a possibility that NPOs or CBOs may operate for-profit enterprises with rewards confined to the members of the institution. Indeed, there is literature demonstrating that some NPOs distribute profits to members (Rothschild and Whitt, 1986; Whyte and Whyte, 1992; Turnbull, 1995).

In light of the above scrutiny of the three major institutions operating in the social sector, the paper has different working definitions for each of them. An NGO is defined as not-for-profit institution that raises money from grants and donations to participate in social value creation. An NPO is defined as not-forprofit institution, made of people who have common interest, created to further the interest of their members only, which otherwise will not be advanced through individual, unorganised action. Finally, social entrepreneurship is defined as for-profit institutions which use commercial entrepreneurial ventures and the resulting profits for social value creation and for sustaining the institution. Common in all definitions of the identified institutions of interest within the three sector economy background is the for-profit and not-for-profit, and private and social value creation terms. The paper uses these terms to develop an institution-entrepreneurial matrix that categorise each of the institutions to one of the four

${ }^{5}$ O'Neill (1989) defines NPOs as private organisations with a public or social purpose. In the context of this paper, such an NPO is treated as an NGO. This interchange is not uncommon, given that Salamon and Anheier (1996) state that the term NGO is, at tim es, used to depict NPOs in developing economies. 
types as shown in figure 1. Although a continuum is likely to exist amongst the distinct forms of institutions provided in figure 1, a clear conceptual framework and distinction remains salient especially in understanding who does what, for whom and how in the economy.

\section{Figure 1: Institution-Entrepreneurial Matrix}

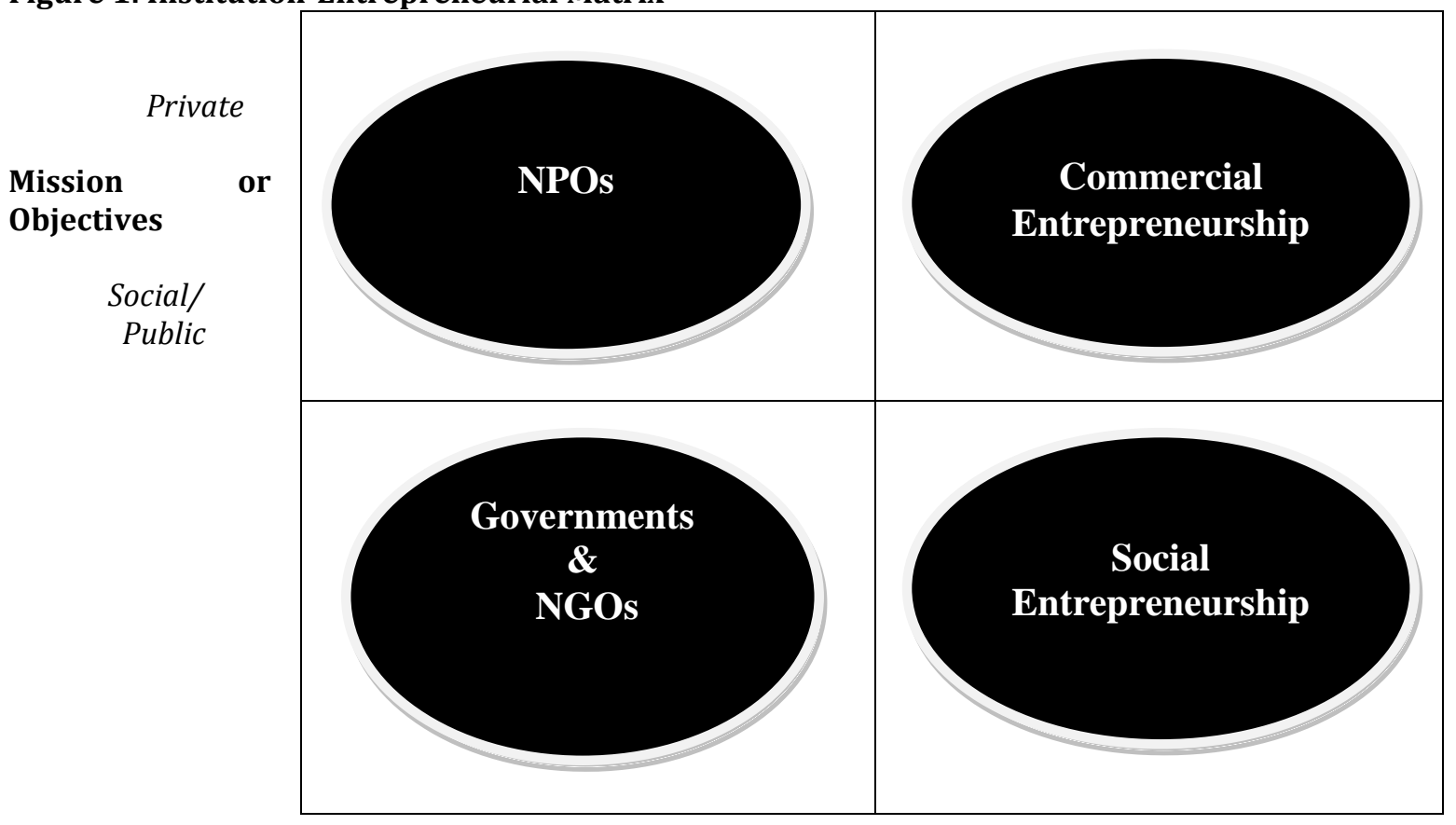

Not-for-profit

Venture

\section{Institutions-Actions Model}

Theorising institutions has long been dominated by sociologists (Hughes, 1939; Selznick, 1949, 1957; Gidden, 1976, 1979, 1984) and organisational studies (Meyer and Rowan, 1977; Powell and DiMaggio, 1991; Barley and Tolbert, 1997). Economists could have concentrated on institutional economics by 1919 (see Hamilton, 1919). However, the great depression and Keynes' solutions to it quietened the movement of institutional economics. It was the work by economists such as Marshak $(1954,1955)$ that revamped the need to understand institutions from an economic point of view. In 1975, Williamson (1975) coined the term new institutional economics and since then, the field has been on the rise (for example, see Masahiko, 2001; Eggertsson, 2005; Furubotn and Rudolf, 2005; Claude and Shirley, 2005; Alston, 2008 and many other articles in the Journal of Institutional Economics).

Institutional economics focuses on evolutionary processes and the role of institutions in shaping arrangements, decisions, actions and behaviour. Equally, institutions arise from strategic decisions and actions. There is, therefore, interdependence between institutions and actions. Yet institutional economists and sociologists have concentrated on the institution's capacity to shape and constrain action (Whittington, 1992). Taking advantage of this knowledge gap, Barley and Tolbert (1997) developed a model of the relations between actions and institutions. Their model succinctly captures the reciprocity between actions and institutions through time in which institutions shape and constrain actions that create them and strategic decisions and actions modify the same institutions.

In figure 2, the bold horizontal arrows depict the two realms - institutions and actions - and their evolutionary process through time. The vertical and diagonal arrows ( $a$ and $b$ respectively) depict the interaction between institutions and actions. Vertical arrows represent constraints imposed by institutions on action, while diagonal arrows represent modification of the institution through action. Given the aim of understanding who creates social value, for whom and how, the paper builds on Barley and Tolbert's (1997) model and on the literature that shows the dynamism of entrepreneurship in pursuit of opportunities within the context of social value creation. The model is not exclusive to entrepreneurship and applies to institutions of any kind in general. The next section of the paper contextualises the model within non-government entrepreneurial dynamics because these institutions 
are quick to adapt to change and seize new or untapped opportunities, compared to government institutions. As entrepreneurs turn strategic decisions to actions in pursuit of opportunities in the economy, Barley and Tolbert's model helps in understanding that such actions modify the realm of institutional entrepreneurs.

Figure 2: Barley and Tolbert's Recursive Model of Institutions and Actions

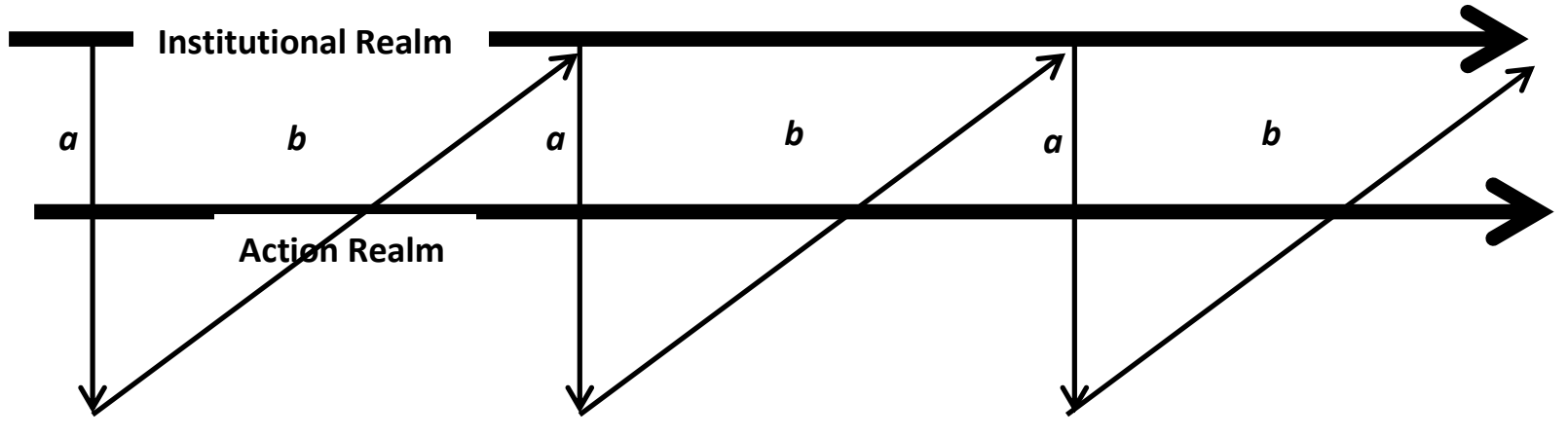

To avoid a mire of complexity in institution-entrepreneurial dynamics, the paper utilises the institutionentrepreneurial matrix developed in the previous section. The matrix will allow for a deeper understanding on who, how and for whom social value is created in the face of institutionentrepreneurial dynamics. Here, the question turns out to be, what actions lead to modification of the institutional-entrepreneur? They are definitely many, depending on the opportunities at hand (see Sahlman, 1996). To reduce the task, the opportunities and strategic decisions and actions will be limited to the context of this paper - that is, to social value creation, and partially to economic returns (for-profit ventures).

Mission Drift Scenarios: In figure 1, there are four categorisations made. There are governments and NGOs in the category of institutions that are not-for-profit and pursue social value; NPOs are in the category of institutions that are not-for-profit and pursue private value; commercial entrepreneurship is in the category of institutions that are for-profit and pursue private value; and social entrepreneurship is in the category of institutions that are for-profit and pursue social value. The entrepreneurial actions within institutions in the categorisation can be threefold, that is, entrepreneurs can abide by institutions, can evade institutions, or alter institutions (Henrekson and Sanandaji, 2011). Attention is directed at institutional-altering entrepreneurial dynamics within the social value creation landscape.

If for-profit decision is made: Using the institution-entrepreneurial matrix in figure 1, institutions that may make a decision to pursue for-profit ventures are NPOs and NGOs. NPOs' income is derived not from sales of goods and services, but from subscriptions of members. Income of NGOs is derived from donations obtained from diverse sources. There may be many reasons why subscriptions may not be enough for NPOs to pursue the common interests of members, or why donations may not be enough for NGOs to pursue social interest. This paper does not attempt to cover these reasons. In the event that subscriptions or donations are not enough, NPOs and NGOs may turn to for-profit ventures to supplement subscriptions and donations respectively. This action introduces commercial entrepreneurship in otherwise non-commercial entrepreneurial institutions. The questions become, do these institutions remain in the not-for profit category, or they shift into for profit categorisation? If there is a shift, do they become commercial entrepreneurs or social entrepreneurs? Figure 3 helps to answer these questions.

Figure 3: Nonprofit Institutional Alteration

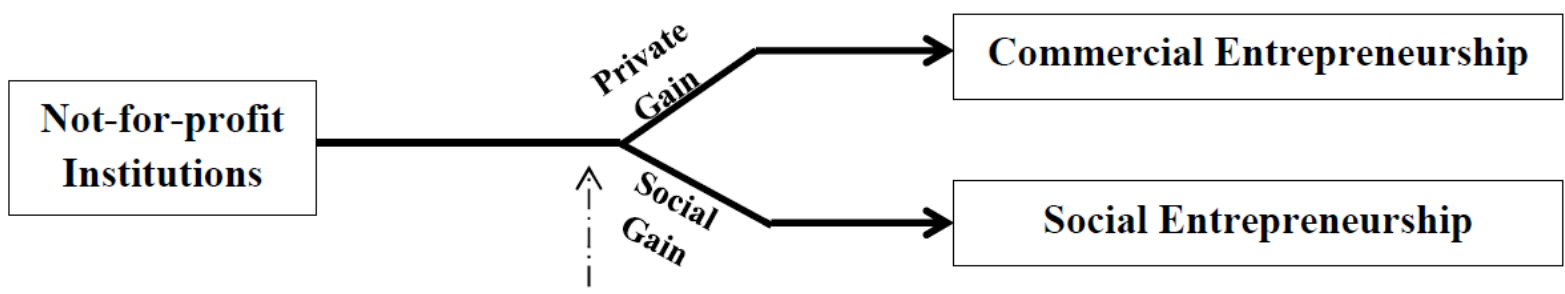

If for-profit venture decision is made 
It makes sense to differentiate an NPO or NGO that has commercial entrepreneurial activities embedded in their revenue generation strategies from that NPO or NGO which does not have such activities. United Nations' (1968) System of National Accounts designates organisations that receive half or more of their revenue from contributions as NPOs and those organisations that receive half or more of their revenue from commercial entrepreneurial activities as the business sector or for-profit category. The paper builds on this designation, and further asserts that it is also necessary to split the for-profit category into commercial and social entrepreneurship. Again here, the designation is that those NPOs that use half or more of their profits to pursue social value creation and the remainder for sustaining the organisation (and not for distribution to shareholders) become social entrepreneurs. This categorical understanding is shared with the United Kingdom Department of Industry and Trade (2002). NPOs that confine their profit to members only shift to being commercial entrepreneurs. In this sense, these NPOs may be treated as not different from small, medium and large businesses that pursue economic value for a private purpose. NGOs, in the matrix, are categorised as pursuing social value through serving and empowering neglected populations, engaging in policy advocacy for social change and providing public services. Using the same analysis as done for NPOs, NGOs that turn to commercial entrepreneurial activities to supplement their donations shift into the category of for-profits if the economic returns they make contribute half or more of their revenue. Within this category, NGOs are most likely to be social entrepreneurs since they originate to pursue social value, with or without the use of commercial entrepreneurial profits to sustain their operations.

Few cases may be used to substantiate the realism of the simulations in figure 3. First, it may be essential to note that cooperatives, mutual societies, associations, unions and all institutions not owned by shareholders have always existed, yet somehow they did not attract the term social entrepreneurship. If anything, they were merely seen as institutions operating in the social sector, especially in the European context (Evers and Laville, 2004). And again, these organisations were not seen as businesses or marketoriented organisations. However, social enterprises, at least in the United Kingdom and Ireland, have been considered as businesses and market-oriented enterprises (Defourny and Nyssens, 2010a and 2010b). What then, are the developments that have attracted the term social entrepreneurship to be used by academics and policy makers? Kerlon (2006) observed such developments from community or religious based organisations in the United States. These groups started selling homemade goods or holding bazaars to supplement voluntary donations. Alter (2007), first by providing a historical account of social enterprises, locates the commercial entrepreneurial ability of NPOs in establishing initiatives that create jobs for those excluded in the labour market. These are some of the examples providing evidence that NPOs may operate as commercial entrepreneurs by turning to the market to generate revenue for their activities.

If social value creation decision is made: Commercial entrepreneurs use for-profit ventures to pursue economic returns for a private gain. Sahlman (1996) developed a model which emphasize that people, context, deal and opportunity (PCDO) are key elements for the success of commercial entrepreneurship. People refer to those who bring resources to the entrepreneur; context refers to the outside environment; deal refers to the contents of the bargain; and opportunity refers to the activity that needs allocation of resources in hopes of an economic return. Within the PCDO framework, it is obvious that commercial entrepreneurs will devote resources to any opportunity that will lead to a deal that eventually makes people to bring resources to them, factoring in the context they operate in. In the past few decades, commercial entrepreneurs have seen opportunities in social value creation that will lead to higher economic returns and competitive and sustainable advantages. The environment, notably civic and social movements, has been dictating that commercial entrepreneurs should plough back to communities where they create their economic values, or some people have boycotted products and services that are produced through socially irresponsible means, such as using child labour. As a result, commercial enterprises have committed resources to this end.

There is no doubt that commercial entrepreneurs create social value in this sense. But do they become social entrepreneurs? Figure 4 simulates the entrepreneurial realms that may result if a for-profit institution takes an action of pursuing social value. First, the analyses focus on the for-profit institution that is a commercial entrepreneur. Given that businesses pursue social value with an intention of cutting a deal that may result in an entrepreneurial return or that may increase the number of people who may bring in resources, it can be said in explicit terms that they are using social value creation as a means to an end. In other words, only a handful proportion of profit is directed towards social value creation. Similar to the approach used to categorise a move from NPO to for-profit sector, any commercial 
entrepreneur that appropriates half or more of its raised profits for social value creation becomes a social entrepreneur. The one that appropriates half or less retains the realm of commercial entrepreneurship.

Figure 4: For-profit Institutional Alteration

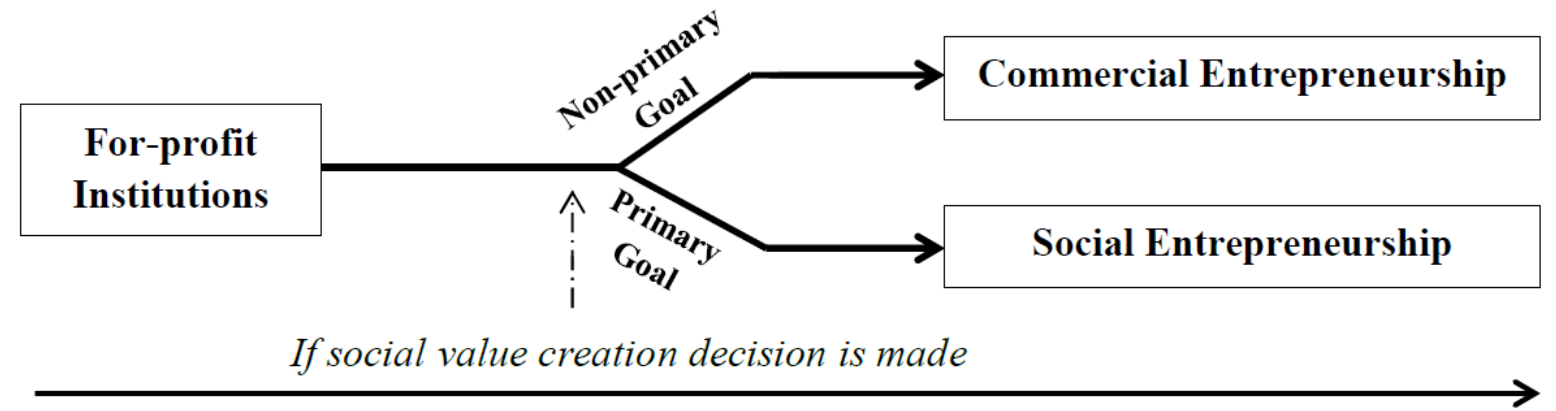

Time

The factor that complicates the shift from commercial to social entrepreneurship is the distribution of profits. The working definition adopted in this paper requires that the profits not used for social value creation be used to sustain the institution. If the profits are distributed to shareholders, then the realm is distorted. However, it could be that the profits distributed, since they will be a smaller proportion compared to profits appropriated for social value creation, are for sustaining the shareholders, in essence sustaining the entrepreneurship. Whilst this is not social entrepreneurship in the strictest sense, it however confirms that there is a continuum between social and entrepreneurship. The triple alliance of The Coca-cola Company, SABMiller and Oxfarm is an example that can substantiate the simulation made above. In their report that explores the links between business and poverty reduction, the letters from the leadership of The Coca-cola Company and SABMiller stressed that 'the success and sustainability of our business is inextricably linked to the success and sustainability of communities in which we operate' and that 'our business will succeed if we manage our relationship well, use resources efficiently, and meet the needs of our consumers and the communities in which we operate', respectively (Oxfarm America, 2011: 9 , 11). Oxfarm America, which has been advocating for the world's poor for a long time, also asserted that 'companies are beginning to recognise that their long-term prospects are intrinsically linked to the prosperity and well-being of the poor countries in which they operate' (see p. 8).

In the same report, Oxfarm America reports that, six years ago, The Coca-Cola Company launched 'Live Positively', an endeavour that included philanthropic activities to foster sustainable communities through economic development and the creation of social opportunities. In 2011, it then partnered with SABMiller and Oxfarm America to identify features, within their value chains, where they can create social value for communities. One of the areas identified include water and recycling. In El Salvado, municipal water treatment plants are lacking. The proposal and discussion on wastewater treatment has been well received by the communities in that country. In Zambia, the triple alliance has already provided standpipes with free clean water to community members. All these efforts are done to gain a competitive and sustainable advantage for private gain. Consequently, commercial entrepreneurs such as The Cocacola Company and SABMIller remain in the commercial entrepreneurship category despite taking part in social value creation. Focus is now turned to for-profit institutions that appropriate more than half of their profit to social value creation - the social entrepreneurs. These may also turn into commercial entrepreneurship if more than half of their profits become available for distribution to shareholders. An example to substantiate this simulation is drawn from Auerswald (2009: 53) who provides a case titled 'From Social Entrepreneur to Corporate Titan' and is sketched as follows:

India's Tata Group has for decades been among that country's largest and most influential industrial conglomerate...It may come as a surprise, then, to learn that the founder of the Tata Group, Jamsetji Tata, was one of the world's first and most success social entrepreneurs...Tata build a business empire that defined its mission as creating both profits and social value. Tata, who died in 1904, is quoted on the Tata Group's Website as saying, 'In a free enterprise, the community is not just another stakeholder in business, but is in fact the very purpose of its existence'...It is almost impossible to visit India and not be aware of Tata Group's presence. It includes not only the industrial entities, but also a stunning array of public services institutions, including the Tata Cancer Hospitals, Tata Institute of Social Sciences, Tata Trust, and the Indian Institute of Science in Bangalore (founded by Jamsetji Tata). More than an illustration, the Tata story is an allegory...the social entrepreneur became the corporate titan. The bottom 
line, in the analyses of the for-profit institution category, is that once the decision to pursue social value is made, the institution may either be a commercial or social entrepreneur, depending on how the profits are used. In addition, there is of course, a continuum between the two types of entrepreneurial institutions.

\section{Discussion}

Each type of institution in the three sector economy has specific objectives that explains and validates its existence. Commercial entrepreneurs pursue economic value through market exchange which results in economic efficient outcomes. However, efficiency may not translate into fairness. Consequently, the government and NGOs have a distinct role of re-distributing resources from the wealthy to the poor to improve fairness. The government does this through taxing income of high earners while NGOs elicit for donations. The role of social entrepreneurs is to solve societal problems using for-profit ventures. Their existence is distinct from that of commercial entrepreneurs in that the latter creates social value to seek competitive and sustainable advantages in their pursuit of economic returns for private gain. Social entrepreneurs are also distinct from NGOs in that they actively engage in commercial entrepreneurial activities to raise funds for social value creation on a sustainable base. By deriving utility from social value creation, addressing this through commercial entrepreneurial activities, and not through taxation and donations which make other economic agents worse-off, social entrepreneurs are well positioned to create a win-win situation in solving a myriad of societal problems. In principle, the unique realm of social entrepreneurship in social value creation is the realisation of nuanced pare to improvements.

The realm of social entrepreneurship and its potential for nuanced pare to improvements is especially important for developing economies where a significant part of the world population is financially and socially excluded and does not have the capacity to transform themselves out of their problems. In some of these economies, governments fail to perform their roles. The private sector is a minor domain because the majority of the population may not engage in market exchange for lack of financial means. NPOs that drive common interests are weak or not present at all. NGOs may not be allowed to operate, or if they are, they will be overwhelmed with demand to achieve transformative social welfare. There is, therefore, a role for entrepreneurs that can identify problems associated with societies living in these economies, develop sustainable innovative entrepreneurial activities to address the problems and transform societies out of misery. The objective of pursuing social value creation might be the new economic fuel for economies with a significant segment of the population who reside in the unjust equilibrium, or it could be the new approach of achieving transformative social welfare. Social entrepreneurs have been creating new business models that provide solutions to basic human problems and transform huge numbers from an unjust equilibrium to be potential customers for commercial entrepreneurs in the private sector. For example, the growth of the microfinance industry has brought financial inclusion to many people who were financially excluded (Seelos and Mair, 2005). These efforts have potential to bring millions of new consumers into the private sector with a potential economic value creation of $\$ 4$ billion (Prahalad and Hammond, 2006) and important consequences on economic growth.

The pursuit of societal or others interest is unfortunately not consistent with Adam Smith's theory of the invisible hand where the central assumption is that the self-interest of economic agents drives economies. Social entrepreneurs derive utility from addressing the social welfare of others through for-profit ventures. The entrepreneurial returns from social entrepreneurs is ploughed back to the community, or used to sustain the institution. Nonetheless, Adam Smith acknowledged that the desire to help others was an important element for personal fulfilment (Smith, 1976). Unfortunately, this concept did not gain wide acceptance among economists as much as the self-interest motive. Therefore, the concept of social value and the unique realm of social entrepreneurship in its creation demonstrate the need to posit the explicit objective of social value creation in the economic theory of the firm. This may widen alternative models outside the objective of profit maximisation. The role performed by commercial enterprises in influencing pro-poor ends cannot go unnoticed. It is clear that persistent social problems cannot be solved by governments, NGOs, NPOs and social entrepreneurs alone. It is obvious that commercial enterprises are led by an invisible hand to provide solutions to pressing societal problems. Likewise, it could be that if commercial enterprises had their way, they would not engage in such philanthropic activities. They only do it for their competitive and sustainable advantages. Therefore, whether intentional or not, they do create social value, and it also contributes to alleviating problems of the population in an unjust equilibrium. 
Entrepreneurial dynamics are a result of opportunities, openings and challenges that continue to emerge within the three sectors of the economy. As noticed by Kerlon (2006), challenges faced by institutions in the United States led them to take actions to supplement their contributions through commercial entrepreneurial activities. Also, a failure by one institution may present an opportunity for the creation of a new institution, or a change in the institutional realm of the other. Therefore, objectives that explain and validate the existence of institutions do change and this is inevitable. As strategic decisions and actions are taken, the realm of institutions adjusts and it is important for public policy and researchers to continually manage the dynamic fit of such changes. A failure to do so would mean that policy governing operations of different types of institutions would lag behind and misleading statistics may be gathered as to which institution does what, how and for whom. There is already a mix-up as to who should be counted as a social entrepreneur. In some quarters, NGOs (or NPOs that pursue social interest outside that of members) are counted as social entrepreneurs. A better understanding of this is undoubtedly needed, especially as competition for grants and service contracts increases. It is also important for taxation policies, as most social entrepreneurs are exempted from paying tax. Researchers also need a proper dynamic fit for such changes to justify the existence and distinctiveness of the discipline of social entrepreneurship. This way, the unique realm of social entrepreneurship may be captured, understood and more research will be advanced into capacity building and growth of this type of entrepreneurship.

\section{Conclusion}

By examining in detail the focal institutions that operate in a three-sector economy, the paper, at the risk of oversimplifying and over narrowing the scope, developed an institution-entrepreneurial matrix that explains and provides clarity on who creates social value, for whom and how. Governments and NGOs were identified as being able to create social value through redistribution of resources. Commercial entrepreneurs were found to create social value to gain competitive and sustainable advantages for their economic return. Social entrepreneurs were identified as being able to create social value while achieving pare to improvements. Consequently, the paper positioned social entrepreneurs as having a unique realm in social value creation to a population segment in an unjust equilibrium. The paper simulated the entrepreneurial dynamics that are likely to, or that have taken place, within the social value creation context. As the results showed, it is possible, despite changes in institutional realms, to still point out NGOs, NPOs, commercial and social entrepreneurs and not allow mix-ups to reign. However, such institutional adjustments may, if not well understood, provide challenges especially for public policy. If researchers and policy makers are not careful, social entrepreneurship can be any activity within and across governments, NGOs, NPOs and commercial entrepreneurs. This need not be. For it will cloud the potential role of social entrepreneurship especially in developing countries where there is an overwhelming demand for its presence.

In these economies, there are political instabilities and governments fail to effectively redistribute resources. The results are significant segments of societies left vulnerable, outside the reach of social services, financial markets and without means to participate in the private sector. There is therefore no doubt that social entrepreneurs have a role to play here. An example provided was microfinance that has brought financial inclusion to many poor households and potential for hope in their transformation out of an unjust equilibrium. Future research in this area could possible identify institutions that purely have for-profit ventures, pursue a social value creation objective and do not distribute profits to shareholders. This will discontinue the practice of counting and using any non-profit institutions, including NPOs and NGOs, as social entrepreneurs. It will also help in the assessment of the actual stock or numbers of social entrepreneurs in the strictest sense. Furthermore, this will go a long way in understanding the impacts of these enterprises not only in social value creation, but in other innovative approaches as well.

\section{References}

Acs, Z. J., Boardman, M. C. \& McNeely, C. L. (2011). The social value of productive entrepreneurship. Small Business Economics, 40, 785-795.

Ahmad, N. \& Hoffmann, A. N. (2008). A framework for addressing and measuring entrepreneurship. Paris: OECD.

Alter, K. (2007). Social enterprise typology. Virtue Ventures LLC.

Alston, L. J. (2008). New institutional economics. The New Palgrave Dictionary of Economics, $2^{\text {nd }}$ Edition.

Auerswald, P. (2009). Creating social value. Stanford Social Innovation Review, 7(2), 50-55. 
Austin, J., Stevenson, H. \& Wei-Skillern, J. (2006). Social and commercial entrepreneurship: same, different, or both? Entrepreneurship: Theory and Practice, 30(1), 1-22.

Barley, S. R. \& Tolbert, P. S. (1997). Institutionalisation and structuration: studying the Links between action and institution. Organisational Studies, 18(1), 93-117.

Barr, A., Fafchamps, M. \& Owens, T. (2005). The governance of non-governmental organizations in Uganda. World development, 33(4), 657-679.

Barro, R. (2007). Bill Gate's charitable Vistas. The Wall Street Journal, June 19, A17.

Baumol, W. J. (1990). Entrepreneurship: productive, unproductive and destructive. The Journal of Political Economy, 98(5), 893-921.

Bennett, J. A., Lossa, E. \& Legrenzi, G. (2003). The role of commercial non-profit organizations in the provision of public services. Oxford Review of Economic Policy, 19(2), 335-347.

Besley, T. \& Ghatak, M. (1999). Public-private partnerships for the provisions of public goods: Theory and an application to NGOs. STICERD Development Economics Discussion Paper: DEDPS/17, London School of Economics and Political Science.

Bhave, M. (1994). A process model of entrepreneurial venture creation. Journal of Business Venturing, 9, 223-242.

Billis, D. (1993). Organizing Public and Voluntary Agencies. Routledge, London.

Bourdieu, P. (1993). The field of cultural production: essays on art and literature. Cambridge, UK: Polity.

Bowman, C. \& Ambrosini, V. (2000). Value creation versus value capture: towards a coherent definition of value in strategy. British Journal of Management, 11, 1-15.

Bozeman, B. (1987). All organisations are public: bridging public and private organisational theories. San Francis-co: Jossey-Bass Publications.

Bruyat, C. \& Julien, P. A. (2001). Defining the field of research in entrepreneurship. Journal of Business Venturing, 16(2), 165-180.

Burgelman, R. A. (1983). Corporate entrepreneurship and strategic management: insights from a process study. Management Sciences, 29, 1349-1364.

Burgelman, R. A. (1984). Designs for corporate entrepreneurship in established firms. California Management Review, 26, 154-166.

Burns, T. \& Helena, F. (1987). The shaping of social organisation: Social rule system theory application. London: Sage.

Calabresi, G. (1968). Transaction costs, resource allocation, and liability rules. Journal of Law and Economics, 11, 25-45.

Cannon, C. (2000). NGOs and the state: A case study from Uganda. In Development, NGOs, and civil society, ed. J. Pearce, 109-114. Oxford: Oxfam.

Casson, M. (1982). The entrepreneur: an economic theory. Barnes and Noble, Totowa, NJ.

Claude, M. \& Shirley eds, M. M. (2005). Handbook of New Institutional Economics. Springer, Preview.

Coase, R. (1960). The problem of social cost. Journal of Law and Economics, 1, 1-44.

Collins, O. F. \& Moore, D. G. (1964). The enterprising man, East Lansing, MI: Michigan State University.

Cunningham, B. \& Lischeron, J. (1991). Defining entrepreneurship. Journal of Small Business Management, $29,45-61$.

Dees, J. G. \& Anderson, B. B. (2006). Framing a theory of social entrepreneurship: building on two schools of practice and thought. Research on social entrepreneurship, ARNOVA Occasional Paper Series, 1(3), 39-66.

Dees, J. G. \& Anderson, B. B. (2003). For-profit social ventures. International Journal of Entrepreneurship Education (special issue on social entrepreneurship), 2, 1-26.

Dees, J. G., Anderson, B. B. \& Wei-skillern, J. (2004). Scaling social impact: strategies for spreading social innovations. Stanford Social Innovation review. Leland Stanford Jr. University.

Defourny, J. \& Nyssens, M. (2010a). Social enterprise in Europe: at the crossroads of markets, public policies and third sector. Policy and Society, 29, 231-242.

Defourny, J. \& Nyssens, M. (2010). Conceptions of social enterprise and social entrepreneurship in Europe and the United States: convergences and divergences. Journal of Social Entrepreneurship, 1(1), 32-53.

Desai, S. \& Acs, Z. J. (2009). A theory of destructive entrepreneurship. Max Planck Institute of Economics, Working paper.

Dixit, A. \& Olson, M. (1997). Does voluntary participation undermine the Coase theorem? Princeton: Princeton University.

Drucker, P. F. (1995). Innovation and entrepreneurship. New York: Harper Business: 28.

Eggertsson, T. (2005). Imperfect institutions: opportunities and limits of reform. Michigan: University of Michigan. 
Emerson, J. \& Twersky, F. (1996). New school entrepreneurs: The success, challenge and lessons of nonprofit enterprise creation. San Francisco: Roberts Foundation, Homeless Economic Development Fund.

Evers, A. \& Laville, J. L. (2004). The third sector in Europe. Cheltenham: Edward Elgar.

Farrell, J. (1987). Information and the Coase theorem. Journal of Economic Perspective, 1(2), 113-29.

Furubotn, E. G. \& Rudolf, R. (2005). Institutions and economic theory: the contribution of the New Institutional Economics (Economics, Cognition, and Society). University of Michigan Press.

Gartner, W. B. (1985). A conceptual framework for describing the phenomenon of new venture creation. Academy of Management Review, 10, 696-706.

Glaeser, E. L. (2003). The governance of not-for-profit organizations. NBER Conference Report Series, University of Chicago Press, Chicago, London.

Gidden, A. (1976). New rules of sociological method. London: Hutchinson.

Gidden, A. (1979). Central problems in social theory. Berkeley, CA: University of California Press.

Gidden, A. (1984). The constitution of society. Berkeley, CA: University of California Press.

Godelier, M. (1999). The enigma of the gift. Cambridge, UK: Polity Press.

Greenwald, B. \& Stiglitz, J. E. (1986). Externalities in markets with imperfect information and incomplete markets. Quarterly Journal of Economics, 101, 229-64.

Haugh, H. \& Tracey, P. (2004). The role of social enterprise in regional development. In Social enterprise and regional development conference, ed. Cambridge-MIT Institute, 16 September 2004. University of Cambridge, UK, Cambridge: Cambridge-MIT Institute.

Hamilton, W. H. (1919). The institutional approach to economic theory. American Economic Review, 9(1), 309-318.

Henrekson, M. \& Sanandaji, T. (2011). The interaction of entrepreneurship and institutions. Journal of Institutional Economics, 01, 47-75.

Hughes, E. C. (1939). Institutions. In R. E. Park ed. An outline of the principles of sociology, 283-346. New York: Barnes and Noble.

Jagannathan, S. (2003). The role of non-governmental organizations in primary education: a study of six NGOs in India. Washington: World Bank Working Paper 2530.

Johannisson, B., Ramirez-Pasillas, M. \& Karlsson, G. (2002). The institutional embeddedness of local interfirm networks: a leverage for business creation. Entrepreneurship and Regional Development, 14, 297-315.

Kerlon, J. (2006). Social enterprise in the United States and Europe: understanding and learning from the differences. Voluntas, 17(3), 247-263.

Kilkenny, M., Nalbarte, L. \& Besser, T. (1999). Reciprocated community support and small-town small business success. Entrepreneurship and Regional Development, 11, 231-246.

Kirzner, I. M. (1973). Competition and entrepreneurship. Chicago: University of Chicago Press.

Learned, K. E. (1992). What happened before the organization? A model of organization formation. Entrepreneurship Theory and Practice, 17(1), 39-48.

Leonard, K. L. (2002). When both states and markets fail: asymmetric information and the role of NGOs in African health care. International Review of Law and Economics, 22(1), 61-80.

Light, P. (2006). Reshaping social entrepreneurship. Stanford Social Innovation Review, 2, 46-51.

Mair, J. \& Marti, I. (2006). Social entrepreneurship research: a source of explanation, prediction, and delight. Journal of World Business, 41(1), 36-44.

Marshak, J. (1954). Towards an Economic Theory of Organisation and information. In Thrall et al. eds. Decision Processes.

Marshak, J. (1955). Elements for a theory of teams. Management Sciences, 1(2), 127-137.

Martin, R. L. \& Osberg, S. (2007). Social entrepreneurship: the case for definition. Stanford Social Innovation Review, 3, 27-39.

Masahiko, A. (2001). Toward a comparative institutional analysis. MIT Press. http://mitpress.mit.edu/catalog/item/default.asp?tid=8628\&ttype=2.

McClelland, D. C. (1961). The achieving story. Princeton, NJ: D. Van Nostrand.

Mendell, M. (2010). Reflections on the evolving landscape of social enterprise in North America. Policy and Society, 29, 243-256.

Meyer, J. W. \& Rowan, B. (1977). Institutionalised organisations: formal structure as myth and ceremony. American Journal of Sociology, 83, 340-363.

Moe, R. C. (1987). Exploring the limits of privatisation. Public Administration Review, 47, 453-460.

Moe, R. C. \& Stanton, T. H. (1989). Government-sponsored enterprises as Federal instrumentalities: reconciling management with public accountability. Public Administration Review, 49(4), 321329. 
Morduch, J. (1999). The microfinance promise. Journal of Economic Literature, 37(4), 1569-1614.

Mort, G. S., Weerawardena, J. \& Carnegie, K. (2003). Social entrepreneurship: towards conceptualization. International Journal of Nonprofit and Voluntary Sector Marketing, 8(1), 76-88.

Morrison, R. (1991). We build the road as we travel. USA: New Society Publishers.

Musolf, L. \& Seidman, H. (1980). The blurred lines of public administration. Public Administration Review, $40,124-130$.

Nicholls, A. (2006). Social entrepreneurship: new models of sustainable social change. Oxford: Oxford University Press.

Olson, M. (1971). The logic of collection action. Cambridge, Massachusetts: Harvard University Press.

Ormiston, J. \& Seymour, R. (2011). Understanding value creation in social entrepreneurship: the importance of aligning mission, strategy and impact measurement. Journal of Social Entrepreneurship, 2(2), 125-150.

Oxfam America. (2011). Exploring the links between international business and poverty reduction. www.sabmiller.com/files/reports/oxfarm_poverty_footprint_report.pdf

Pearce, J. (2003). Development, NGOs, and civil society. Oxford: Oxfam.

Peltzman, S. (1971). Pricing in public and private enterprises: electric utilities in the United States. Journal of Law and Economics, 14(1), 109-147.

Peredo, A. M. \& Chrisman, J. J. (2006). Toward a theory of community-based enterprise. Academy of Management Review, 31(2), 309-328.

Peredo, A. M. \& McLean, M. (2006). Social entrepreneurship: a critical review of the concept. Journal of Business Venturing, 21(1), 1-26.

Perrini, F. \& Vurro, C. (2006). Social entrepreneurship: innovation and social change across theory and practice. In J. Mair, J. Robinson and K. Hockerts, eds. Social entrepreneurship. Basingstoke: Palgrave Macmillan, 57-85.

Phills, J. A., Deiglmeier, K. \& Miller, D. T. (2008). Rediscovering social innovation. Stanford Social Innovation Review, 1, 34-43.

Powell, W. \& DiMaggio, P. (1991). The new institutionalism in organisational analysis. Chicago: University of Chicago.

Prahalad, C. K. \& Hammond, A. (2006). What works: Serving the poor. Markle Foundation, World Resource Institute.

Putnam, R. D. (2001). Social capital: measurement and consequences. Canadian Journal of Policy Research, 2(1), 72-81.

Quinn, R. E. \& Cameron, K. (1983). Organisational life cycles and shifting criteria of effectiveness. Management Sciences, 29, 33-51.

Reinikka, R. \& Svensson, J. (2003). Working for God? Evaluating service delivery of religious not-for-profit health care providers in Uganda. Technical Report. World Bank Working Paper No. 3058, Washington.

Ridly-Duff, R. \& Bull, M. (2011). Understanding Social Enterprise: Theory and Practice. Sage Publications Ltd.

Rothschild, J. \& Whitt, J. A. (1986). The cooperative workplace. Cambridge University Press, Cambridge.

Sahlman, W. A. (1996). Some thoughts on business plans. In W. A. Sahlman, H. Stevenson, M. J. Roberts and A. V. Bhide eds. The entrepreneurial venture. Boston: Harvard Business School Press, 138-176.

Salamon, L. \& Anheier, H. (1996). The emerging nonprofit sector: an overview. Manchester: Manchester University Press.

Schumpeter, J. A. (1911). The theory of economic growth. New York: Oxford University Press.

Schumpeter, J. A. (1934). The theory of economic development: an inquiry into profits, capital, credit, interest, and the business cycle. Cambridge, MA: Harvard University Press.

Scott, C. \& Hopkins, R. (1999). The economics of nongovernmental organisations. STICERD Development Economics Discussion Paper: DEDPS/15, London School of Economics and Political Science.

Seelos, C. \& Mair, J. (2005). Social entrepreneurship: Creating new business models to serve the poor. Business Horizon, 48, 241-246.

Selznick, P. (1949). TVA and the grass roots. Berkeley, CA: University of California Press.

Selznick, P. (1957). Leadership in administration. New York: Harper and Row.

Singh, R. P. (2001). A comment on developing the field of entrepreneurship through the study of opportunity recognition and exploitation. Academy of Management Review, 26(1), 10-12.

Smith, A. (1976). The Theory of Moral Sentiments. New York: Oxford University Press.

Smith, A. (1776/1976). An inquiry into the nature and causes of the wealth of nations. Oxford: Clarendon Press. 
Stevenson, H. H. (1983). A perspective on entrepreneurship. Harvard Business School Working Paper No. 9-384-131. Boston: Harvard Business School.

Stevenson, H. H. (1985). The heart of entrepreneurship. Harvard Business Review, 63, 85-94.

Stevenson, H. H. \& Jarillo, J. C. (1991). A new entrepreneurial paradigm. In A. Etzioni and P. Lawrence, eds. Socio-economics: toward a new synthesis (pp. 185-208). Armonk, NY: M.E. Sharpe.

Stiglitz, J. E. (1994). Whither socialism. Cambridge, MA: MIT Press.

Stiglitz, J. E. (1998). Distinguished lecture on economics in government: the private uses of public interests: incentives and institutions. The Journal of Economic Perspectives, 12(2), 3-22.

Taylor, M. (1999). The small firm as a temporary coalition. Entrepreneurship and Regional Development, 11,1-19.

Thompson, J. (2002). The world of the social entrepreneur. International Journal of Public Sector Management, 15(5), 412-431.

Timmons, J. A. \& Bygrave, W. D. (1986). Venture capital's role in financing innovation for economic growth. Journal of Business Venturing, 1, 161-173.

Turnbull, S. (1995). Innovations in corporate governance: the Mondragon experience. Corporate Governance: An International Review, 3(3), 167-80.

U.K. Department of Trade and Industry. (2002). A progress report on social enterprise: a strategy for success. http://www.edsols.org/SocialEntStrategyforSuccess.pdf. [Accessed on 2 March 2012].

United Nations. (1968). A system of National Accounts. Series F, No. 2, Rev. 3, United Nations, New York.

Weitzel, U., Urbig, D., Desai, S., \& Sanders, M. (2010). The good the bad and the talented: entrepreneurial talented and selfish behaviour. Journal of Economic Behaviour and Organisation, 76(1), 64-81.

Whittington, R. (1992). Putting Giddens into action: social system and managerial agency. Journal of Management Studies, 29, 693-712.

Whyte, W. F. \& Whyte, K. K. (1991). Making Mondragon. ILR Press, Ithaca, New York.

Williamson, O. E. (1975). Markets and hierarchies, analysis and antitrust implications: a study in the economics of internal organisation.

Woolcock, M. (2001). The place of social capital in understanding social and economic outcomes. ISUMA Canadian Journal of Policy Research, 2(1), 11-17.

Zadek, S. \& Thake, S. (1997). Send in the social entrepreneurs. New Statesman 26-31. 